\title{
Minding your 'Ps and Qs': Poetry, Propaganda, Politics and Pictures
}

\author{
Alison Halliday
}

A s Bradford (2001) reminds us, white Australians should focus on what representations of Aboriginality say about construction of white identity. I wish to compare the evolution of two poems and two picture books, which appear to represent the lives of two very different Aboriginal people, separated by over a hundred years. In these texts, white Australia's positioning and interpreting of the Aborigine reflects the ways in which white society has, over the course of the twentieth century, constructed a role and position for itself that seems to have changed little. One of the ways in which the lack of change is most apparent is in the role of silence in each poem and picture book. It seems contradictory to speak of silence, especially in texts for children, but, as Ruth Wajnryb (2001) has noted, silence is significant as a means of control of (and possibly by) the subject, and also as an indicator of stories that are too horrible to be recalled. I wish to explore not only who speaks or not, but who is silenced and what constructions are used to reinforce this silence. As picture books these stories are being told in a way that may say more about the attitudes of white Australia than is evident in just the words of the original poems.

'The Last of His Tribe' was an early poem of Henry Kendall. Born in 1839, Kendall wrote this poem in September 1864 and included it in his subsequent collection Leaves from the Forest (1869). From this time it became one of the most anthologised poems in Australia's literary history. Curiously, in his last volume, Songs from the Mountains (1880), Kendall included three new poems about A borigines: 'Black Lizzie', 'Peter the Picaninny' and 'Black Kate' which show these people in the most damning and overtly racist terms. Kendall may have been intending to show the inappropriateness of the behaviour, dress and cultural codes of 'those white matrons I have met' ('Black Lizzie') but he writes with an almost vicious delight in his descriptions from Black Lizzie's pipe smoking that 'mars somehow your attractiveness', to Peter who 'never lost his appetite' and Kate who will eat 'a yard of snake, / head and tail and skin and all.' If Kendall intended to celebrate the Aborigine and to condemn imported cultural ideas and artifacts as being inappropriate to this 'new' country of Australia he failed. He commented in a letter to Gordon McCrae that he could 'out blackfellow [Brunton] Stephens' and he called these poems "indisputably Australian" (in Healy 1978, p. 106). Healy comments that Kendall believed he was 'rooting Australian literature into its own soil.' (p.106). Whatever Kendall thought he might have been doing, to the modern reader these poems demonstrate a simplistic, prejudicial and condemnatory view of Aborigines. The earlier poem, 'The Last of His Tribe', may seem to be very different but closer reading, and the poem's later manifestation as a picture book, reinforce the views of Kendall in his later work. It is not surprising that these other poems are not found in later anthologies but some of the covert ideologies that may be seen in 'The Last of His Tribe' and its ongoing presence in literature for Australian children reinforce an ideological position not dissimilar from those of his more overtly racist poems.

What is important here is that these poems are indicative of Kendall's own difficulties with knowing what it may mean to be, personally and more generally, an Australian. 'The Last of His Tribe' reveals a narrator who, as Bradford says 'construct[s] Aboriginal people as a race whom history has passed by' (p.25). There appears to be a desire to separate the Aborigine from the white settlers and I suggest that this is more than just a reflection of assumed social superiority. Even at this early time in white Australia's history this poem may be read as demonstrating why there is no need for the settlers to feel any shame or guilt about interactions of any sort with the Aborigines to this point. The Aborigines are gone and thus the land is empty. This position continued to be reinforced in the 1957 edition of The Selected Poems of Henry Kendall edited by T. Inglis Moore where 'The Last of His Tribe' is the first poem in the section titled 'Past and Future'. Rather than reading the poem as only reflecting Kendall's point of view it may be seen today as a piece of political propaganda. Nevertheless, the more it was, and continues to be, read and urged upon the reader, the more it suggests that it is something to be desired rather than something that was; it is a lie that some may wish to be true.

It may not be surprising that in 1927 when the Melbourne A rgus held a literary competition in an attempt to discover which Australian books were most highly regarded by 
Australian readers, Kendall came third in the poetry section, after Adam Lindsay Gordon and Henry Lawson (Bennett 1998, p.145).

'The Last of His Tribe' was first anthologised in $A$ Golden Treasury of Australian Verse (1909) edited by Bertram Stevens. It held a continued place in anthologies of Australian poems, throughout the twentieth century, both for adults and increasingly for children. In many cases, in these anthologies, it is accompanied by an illustration. An illustration is a powerful tool in directing and controlling a reader's response to a poem, as I have discussed elsewhere (Halliday 1999). Bradford (p.22) points out that 'The Last of His Tribe' was in the Eighth Book of the Victorian Readers from 1940. Here it was illustrated by the figure from the first two lines: an isolated, dejected or even defeated figure:

He crouches, and buries his face on his knees, And hides in the dark of his hair

More recently the poem was included in The Illustrated Ticasury of Australian Verse of 1984 edited by Beatrice Davis, (the highly regarded and influential editor at Angus \& Robertson from 1937 to 1973). In this edition it was illustrated by an unacknowledged painting of an Aboriginal man. This illustration shows an Aboriginal man who would, by virtue of his 'traditional' dress and appearance, seem to have no place in the modern world. The poem was included in the handsome new edition of this antholugy in 2000 revised by the poet Jamie Grant (presumably, at least in part, brought about at this time in response to the nationalism of the changing millenium). In this edition it is illustrated by a painting titled 'One of the NSW aborigines befriended by Governor Macquarie', dating from c.1810-1821. It is worth noting that the last two illustrations, while being deemed appropriate for the modern reader, nevertheless pre-date the poem by at least 40 years. These two illustrations seem to be in response to the description in the poem of the subject as 'a chief, to the rest of his race'.

All three illustrations reinforce the subject of the poem as male, solitary and (apparently) untouched by white culture. The underlying irony here is that all the illustrations have been done by white artists.
'The Last of His Tribe' continued to be selected by editors of anthologies specifically for school use such as Outlook (1992) edited by Ron Pretty, and Two Centuries of Australian Poetry (1988 and 1996) edited by Mark O'Connor. In these anthologies it is either positioned as part of the early literary history of Australia or it is placed with poems about multiculturalism. In both cases the positioning of the poem negates its relevance for today and reduces possible reactions of horror and shame by the reader. It is seen as elegaic, belonging to a distant past. It is a sign of an entrenched, if covert, ideological prejudice that this poem continues to find a place in modern anthologies. In these anthologies for school children the commentary surrounding the poem tends to control the reader's response as when Mark O'Connor (1988) comments that "early white poets, since they did not understand the Aborigines, tended to sentimentalise them, as in "The Last of his Tribe" . (p.32). This comes close to excuse-making on behalf of Kendall.

'The Last of His Tribe' is not found in poetry anthologies for younger readers but many do include other poems about Aborigines and by Aboriginal writers, such as in Heylen and Jellett's Someone is Flying Balloons (1983). This collection includes Oodgeroo Noonuccal's reply poem 'Last of His Tribe', and it is not illustrated.

In 1989 The Last of His Tribe was published as a picture book illustrated by Percy Trezise and Mary Haginikitas. It was one of a number of picture books at this time which retold Aboriginal stories and myths in the series that had been started with a collaboration of over twenty years between Dick Roughsey and Percy Trezise and then continued for a few more titles with Trezise working with Mary Haginikitas. In this series it was the only poem, the only story that was not connected to an Aboriginal story, and the only text written by a white Australian. As a poem in picture book form it also became part of small collection of picture books that honour iconic Australian poems such as Paterson's Waltzing Matilda (illustrated by Desmond Digby), The Man from Snowy River (illustrated by Annette Macarthur-Onslow) and Mulga Bill's Bicycle (illustrated by Kilmeny and Deborah Niland); Ethel Turner's Walking to School and C.J. Dennis's Hist (both illustrated by Peter Gouldthorpe). These texts are clearly 


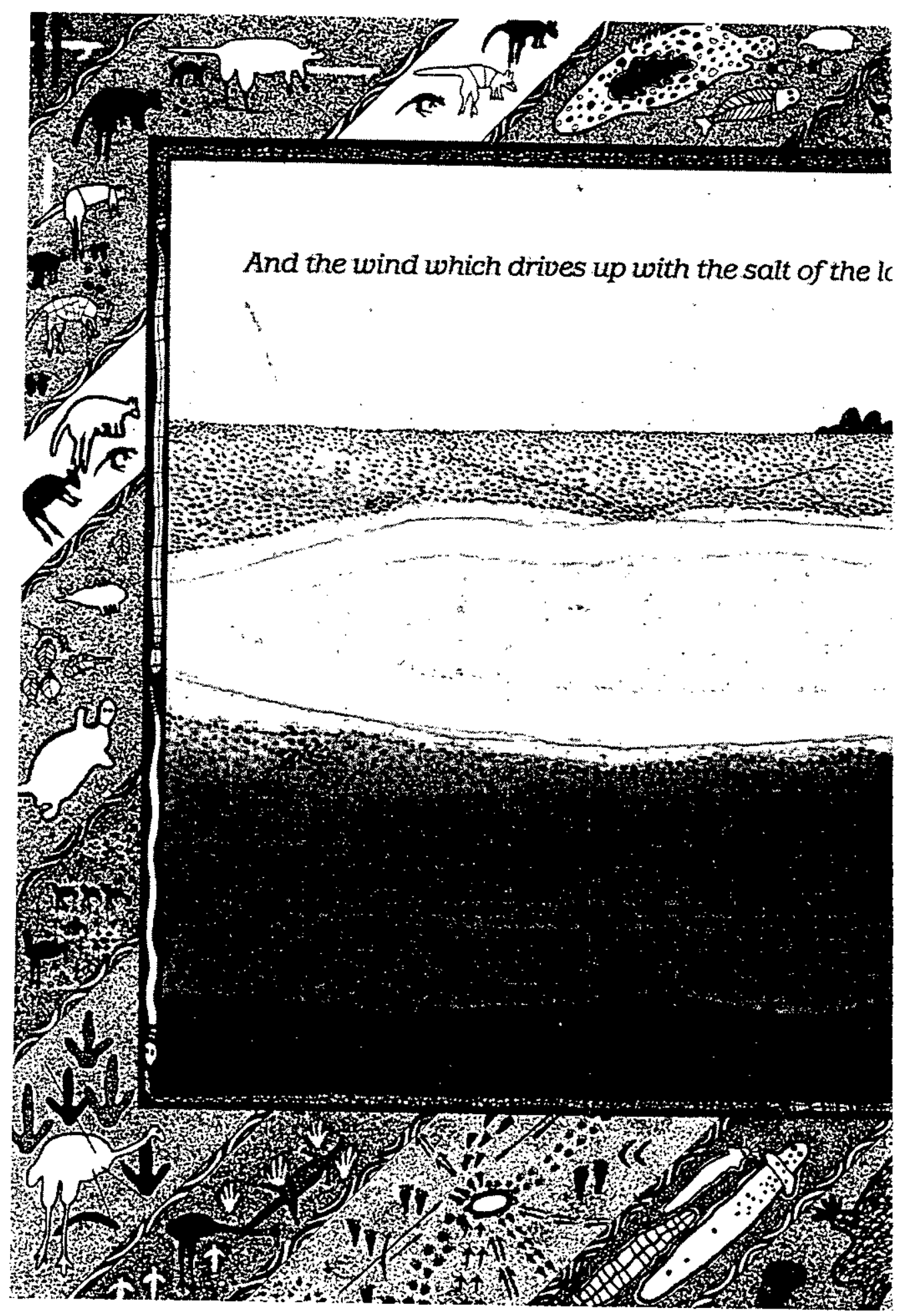

Image from The Last of His Tribe (1989) by Henry Kendall, illustrated by Percy Trezise and Mary Haginikitas (Sydney, Collins Publishers Australia in association with Anne Ingram Books) reproduced with permission from HarperCollins. 


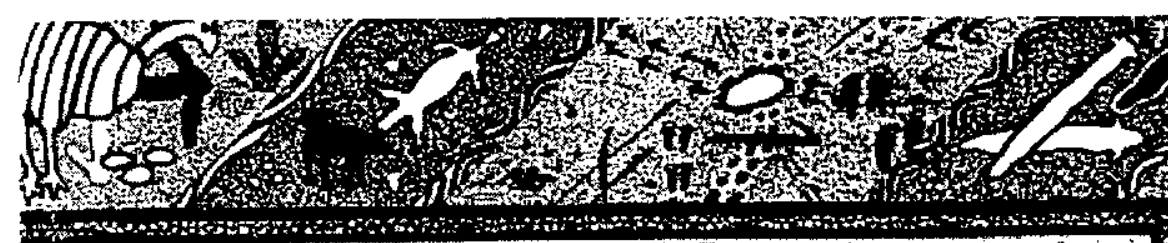

Have made him a hunter again A hunter and fisher again.

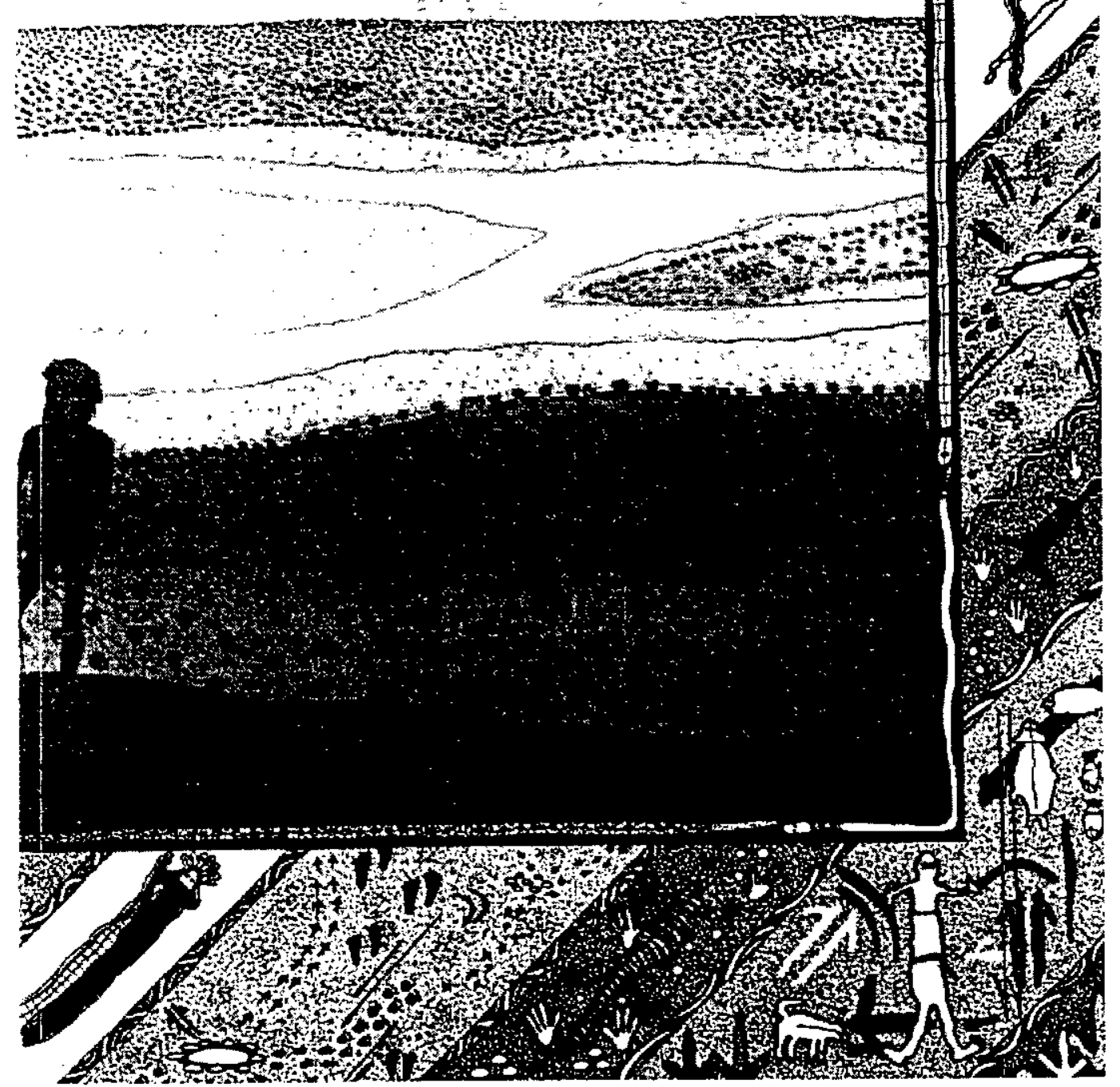


for the child reader. They have been appropriated by adult readers and publishers for Australian children and in so doing they reinforce certain cultural parameters about childhood, about Australia and, in 'The Last of His 'Tribe', about Aborigines.

The illustrations for the picture book version of The Last of His Tribe are done in a naïve style in full colour. Against the stylised landscape the Aboriginal figure is drawn in a more realistic mode and he increases in size through the text (see pp. 40-1). However he is always shown as still: crouching, sitting or standing. His face is either hidden, partly concealed or shown in profile except for the last, and largest, picture. The pictures echo his isolation which is reinforced by the image of the dingo as his only companion. Other Aborigines, numerous and active, are shown only in the pictures of his dreams and these pictures are all in the second half of the text or poem after the crucial statement in the fourth stanza: 'he dreams of the hunts of yore'. The assumption is that the Aborigines have all vanished. However behind this assumption are the unspoken and unexamined reasons for their vanishing. His isolation is underlined in the last stanza with him being in 'desolate lands' and away from 'the rest of his race'. It is no accident that the illustration for these two lines shows him in three quarter face, at his largest and most upright, as the 'noble savage'. It is only here, at the end of the poem, at the end of the book, at the end of his race, that he may be shown in a positive light. Here, white Australia can afford to be generous.

That he no longer belongs here (in every sense) is also indicated by the presence on this penultimate spread and on the last by other renditions of Aboriginal figures that, it is implied, are by Aborigines themselves. These figures are shown in sepia under the couplet:

Will he go in his sleep from these desolate lands,

Like a chief, to the rest of his race

The poem indicates the two reasons for his leaving: the land is no longer productive, and his people are no longer there. It is on the adjacent page that the subject is shown in his full stature and nobility in a full colour illustration. The last doublespread has a similar juxtaposition with the right hand page showing the 'honey-voice woman' calling him from a mystical and mysterious place. Her remoteness and attractiveness is emphasised by the deep blue background colour and her white head-dress which is echoed by numerous star shapes. On the left hand page the text is at the top of the page and the rest is filled with an all-blue illustration of large rock on which is a small white shape which seems to be that of the woman. The effect, as before, is to suggest not only that where these people really belong is in the past but that this is where they all are but one.

The subject is being called back to the past, to a dream or to some other place where he truly belongs. This final position has been suggested earlier by the double spread picture for the lines:

And the wind which drives up

with the salt of the lakes,

Have made him a hunter again-

A hunter and fisher again

His turned back, the position of the reader looking down on the figure which in turn is looking down and out over the barren landscape, and even the dingo with hanging head all serve to negate the sense of the lines. He will not be able to be a hunter or fisher again. The present landscape offers nothing to him. What he has lost (and what he will come to again at the end of the poem) is shown in the surrounding double frame. This seems to be painting that is 'more' Aboriginal with its dots, decorations and stylised animals. The double frame both isolates and contains him; here is where he should be, not where he is.

'The Last of His Tribe' had another important consequence in Australian poetry. It gave rise to the group of poems by Oodgeroo Noonuccal (previously known as Kath Walker), including one with an almost identical title, which offer a revised version of the position of the Aborigine in white Australia. Here there are both men and women and they are not dead or in the past but their position is shown as being marginalised and fraught with ongoing pain and prejudice. 'Last of His Tribe' was published first in the collection We Are Going (1964). It is almost impossible to read Kendall's poem without also hearing that of Oodgeroo. In the anthology Sing in Bright Colours 
(1975) edited by Mappin the two poems are placed on adjacent pages (pp.12/13). They do not make for a poetic couple of which white Australians should be proud.

As indicated earlier, silence plays a significant part in this poem and in the juxtaposition of text and picture. Wajnryb (2001) comments that the unspoken message is the subtlest of all communication. If we read The Last of His Tribe and listen for the nature of the silence it is possible to hear how the layers of communication embodied in the poem construct something that may be heard as normal, or not perceived at all. Wajnryb emphasises that silence 'is not an absolute, but derives its meaning from the context of occurrence' (p.293). The context here is a white Australian colonial poet seeking identification and ownership of (his) Australia through the overt praise, and covert denial, of an earlier ownership. For the child reader of the picture book the immediate context is also that of the pictures where, as discussed above, the subject is not only diminished but also shown as displaced and silent.

The Aboriginal man in this poem is silenced in many and different ways:

1. He is given no voice; someone else, a white poet, is speaking for him in a language that is not his.

2. Someone else, the narrator, is also expressing his dreams; an impossible utterance as only the dreamer can tell his dreams.

3. Speech is useless as there is no-one to hear or to understand.

4. The form in which is he is being spoken of is meaningless to him as it encapsulates much of the art of poetry of an Anglo-centric tradition.

5. By having no name: he is generic rather than individual.

6. By being referred to by the meaningless title of 'chief'.

7. As a metaphor he is broken and dismissed.

8. He is in and of the past.

9. By making him an inactive warrior and hunter; he is a man of action but he is unable to act.

10. By ending the poem with a rhetorical question: the answer is the reader's.
11. In the picture book he is objectified and distanced in the illustrations.

12. In the other illustrations he is shown as untouched by white people, but he is the object of white representation through the images which show him.

It is easy to say that this poem is of other times and other places. Nevertheless, it is not only still being reproduced, illustrated, read and interpreted but its story of silencing and of desired spatial and temporal displacement is still being told in other forms in our culture; perhaps most obviously within the report on the Stolen Generation.

Over 100 years after Kendall wrote 'The Last of His Tribe', in 1981, a new country and western song was heard. Called 'The Drover's Boy', it was composed and sung by Ted Egan. It was simply sung with the voice accompanied by a rhythm sounded out on a cardboard (beer) box. Since then the song has been sung by other Australian singers such as John Williamson and reproduced on many tapes and CDs such as The Overlanders. It continues to be part of the recording repertoire of Australian country and western singers. As a song it tells a melancholy story but one with a resolution of hope and acceptance.

As a song it is both oral and ephemeral; but it was popular and frequently re-played on radio. The effect of the song's early life is that it is memorable and recognisable; with each performance re-inscribing it as part of Australian's cultural heritage. Investigation of the processes of memory suggests that the more often a memory is recalled or heard the stronger it becomes as the electrical encoding is almost literally burnt deeper into the brain. What continue to be re-inscribed are the first reactions of the listener: the sadness and the possibility of hope in this poignant story. Nevertheless, even as a song it could be heard that this was a story as much of white male Australia as of the disguised Drover's Boy. 'The Drover's Boy' offers what Read (p.116) calls a subtle justification for the physical presence of the writer or narrator. It shows attachment to the land through a physical presence, achievement and hard labour. Read comments that country and western music emphasises that the "harder the labour, the greater the implied right of attachment' (p.118). 
They couldn't understand why the drover cried

As they buried The Drover's Boy,

For the drover had always seemed so hard

To the men in his employ,

A bolting horse, a stirrup lost,

And The Drover's Boy was dead.

The shovelled dirt, a mumbled word,

And it's back to the road aheâd

And forget about

The Drover's Boy.

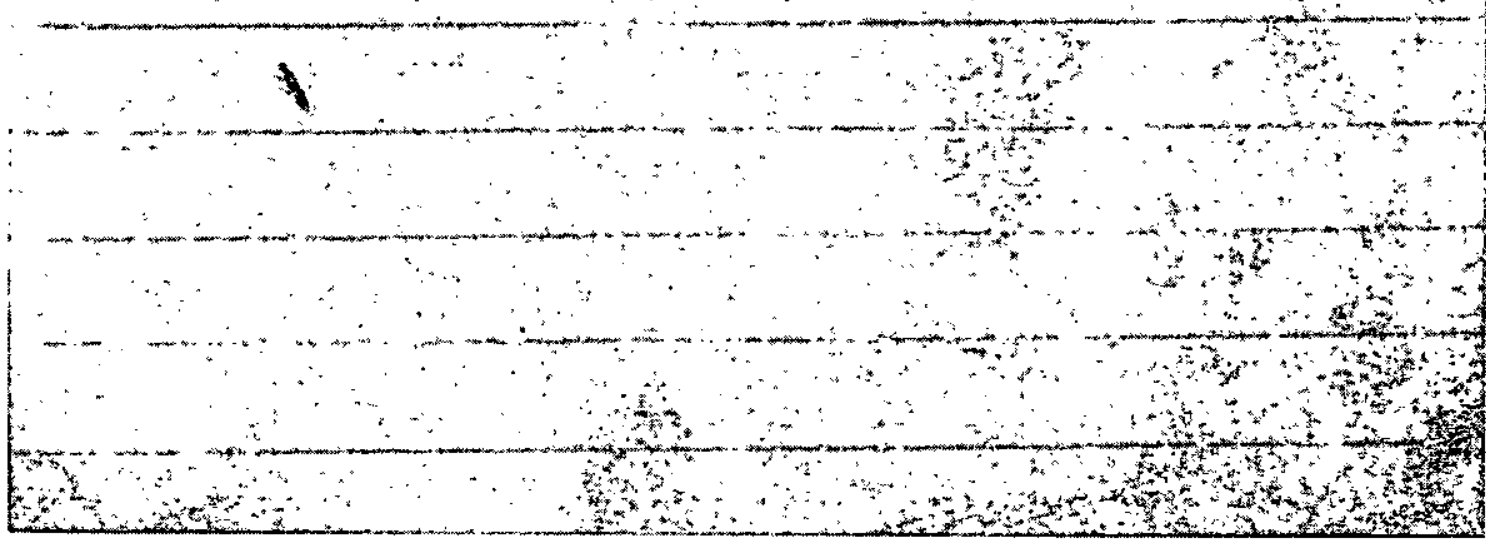

Image from The Drover's Boy (1998) by Ted Egan and Robert Ingpen (Port Melbourne, Lothian Books) reproduced with permission. 


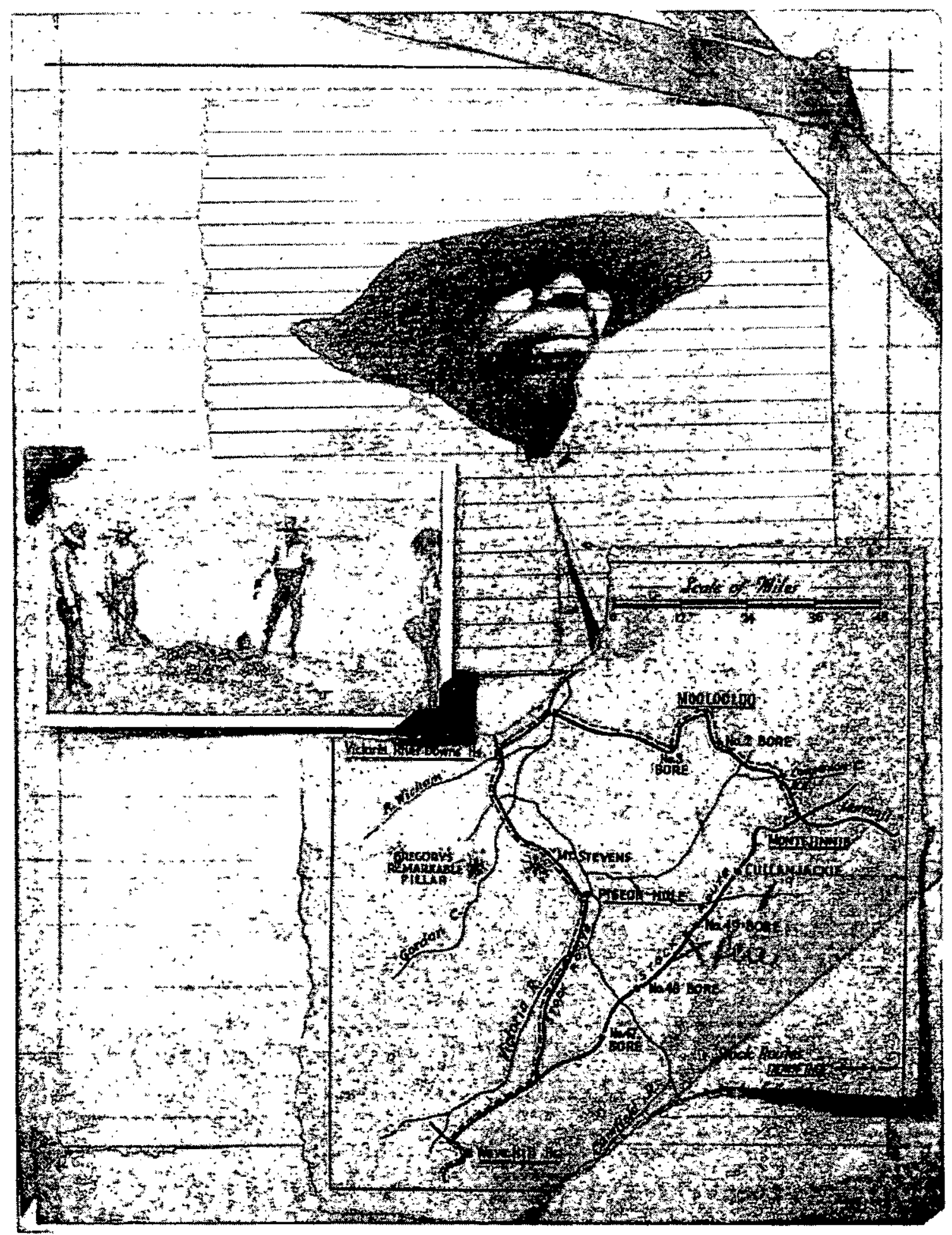

Papers 12: 22002 
In 1997 the song completed its transformation into a poem when it was published as a picture book, with the same title, and illustrated by Robert Ingpen. It joined the group of iconic poems that I mentioned earlier. This text presents the story of the drover's boy in four different ways: as the text of a picture book; as the words of a song, complete with the music; as the re-told collective life story of these pioneering [Aboriginal] women of northern Australia and, perhaps most potently, in the wonderful illustrations by Ingpen. The illustrations literally link all three retellings, for each is embedded in pictorial material. The song words and music are on a double spread showing Aboriginal drovers against a rugged landscape, all in grey and brown tones. The figures are not covered by either script. The life story or history is also on a double spread; the text on the left hand page and the illustration of a full page head of an Aboriginal woman as the backdrop to a man mourning at a grave and cross in the foreground. These re-tellings are on the last four pages of the book. The various re-tellings in text are clearly separated but the strength of Ingpen's illustrations is partly due to all these stories (and voices) being represented at one and the same time.

I want to look more closely at the poem as text and the accompanying illustrations in order to 'unpack' the likely reactions of the listener to the song. In this main text Egan and Ingpen combine the story of the one 'drover's boy' of the first part of the poem, with the possible story of many of the Aboriginal women, and with fragments of documents of white Australians occupying the northern regions of this continent. Here many voices may be heard or seen and the construction of a history is shown to be elusive, fragmentary, layered and incomplete. The illustrations are of two types, on alternate pages (see pp. 44-5). One shows the documents or the evidence, both official and personal, of the stories within the poem (that of the massacre and that of the drover's boy) and prints the words of the poem. On these pages the words of the poem become just another form of written evidentiary material. Thus the first double spread has the text of the first verse of the poem on the left hand page:
They couldn't understand why the drover cried As they buried The Drover's Boy,

For the drover has always seemed so hard

To the men in his employ,

A bolting horse, a stimup lost,

And The Drover's Boy was dead.

The shovelled dirt, a mumbled word, And it's back to the road ahead

And forget about The Drover's Boy

On the adjacent page is a collage consisting of an old photograph of men standing around a newly dug grave, a pencil sketch of the head and torso of an Aboriginal figure where the hat conceals much of the face and a torn part of a printed map on which is a cross and the word "Here" written in pencil. Both the collage and the poem are shown as linked by being on the pages of an old yellowed exercise book. In other words, the picture book of the poem contains another fragmented book which fills every page except for a narrow white margin. The words and the variety of illustrated material are thus literally joined. This has the effect of implying that the poem is just one more way of telling this story. All the illustrations are shown in a restricted palette of sepia and black and white tones. This emphasises the historical context but it also integrates the purely illustrative spreads with those showing the words of the poem and the other retellings.

The other form of illustration consists of a double spread with no text at all. These show the main elements of the story: the death of the boy and the mourning drover; and they also include pictures of Aborigines without temporal markings: just people living and working on the land. In all these double spreads the illustration crosses the gutter of the page. The focus of the picture is in the foreground, for example the bolting horse or the head of the drover as he 'sit[s] with the boy a while'. There are five examples of this type of illustration. The two that specifically relate to the events in the drover's poem are first but the last verses of the poem that tell of the capture of the drover's boy and the building of the Stockman's Hall of Fame are not specifically referred to as they show present day Aboriginal people as stockmen and as groups within the 
landscape. This shift to the present and to a wider representation of Aborigines is emphasised by a growing intensity of tone, the introduction of a wider range of colours and a more clearly delineated landscape.'

As with The Last of His Tribe I want to examine more closely the ways in which silence is present in The Drover's Boy. The silence here is rather more subtle than in 'The Last of His Tribe' because the sheer number of the retellings reinforces the significance of these women.

1. The first is a gap rather than a silence. There is a tension between the multiple voices of the illustrations (both textual and pictorial), and the song/poem and history that Egan narrates. This gap may be due to the actual nature of pictorial versus textual representations but it is also creates a space or silence because the two means are not telling the same story. It is the readers who should fill this silence with their own response.

2. In the whole picture book the women are never given any direct speech. This absence or silence ultimately almost overwhelms what is said.

3. In the words of the poem the drover's boy never speaks

4. The poem begins with the death of the drover's boy so her silence is inevitable. Story order is not chronological so that she begins as an absent voice.

5. The drover's boy is also separated in space: travelling ahead, 'gone at the break of dawn' and camping 'far away'.

6. She is sijenced through the loss of her gender. The other drovers do not realise that she is not a boy. The first three stanzas are focalised though the other men in the camp and each begins with the repeated comment: 'They couldn't understand.'

7. The first two stanzas end with the command to 'forget about The Drover's Boy'. While the poem obviously denies this possibility the choice to remember or not lies with the reader.

8. She is silenced through the incorrect name: "The drover's boy'. This not only reinforces the loss of her real gender but it shows the loss of power and autonomy as she belongs to the drover. The use of 'boy' also implies the derogatory term embedded in colonial narratives.

9. She is silenced because she has been removed from her land, 'a Kimberley run, Fitzroy', and from her people during the 'massacre in the west'.

10. She is silenced because she is equated with a lesser being or even an animal: 'break her in'.

11. She worked and bred sons but could never be legally acknowledged as 'the law prohibited their employment as drovers' (last page). This shift from the poem to the historical story means that the voice of the individual is lost to the collective.

12. She should be placed in or to be seen as part of 'that Stockman's/ Hall of Fame' and the 'droving game', but it seems that she is not.

13. She is objectified, as emotions for her are denied: she is not to be mourned or wept for but only remembered.

Egan finishes the last section 'About the Drover's Boy' with the comment: 'The Drover's boy is a work of fiction based on indisputable historical fact. The song, and this book, present a moving love story as tribute to these women, whose contribution to Australia's history has not previously been recognised. I am not arguing with the worthiness of Egan's intentions; but, ironically, it is the illustrations rather than the poem that do most to break these forms of silence.

In some ways it seems that little has changed over the course of the twentieth century. Both poems show that silence may be used as a tool for deracination; but both picture books attempt to honour the last of his tribe and the drover's boy in the illustrations. Should we see these texts as blatant propaganda, or as a means of attempting to reconcile feelings of sorrow and shame? For white Australian readers, at worst, these texts reinforce a dominant white hegemony as the desired norm of Australian society; at best they may introduce a poem, a life story and a possible history to children at an early age. They are texts which need to be very closely examined and carefully read and shared. 


\section{NOTES}

1. The most recent manifestation of 'The Drover's Boy' is as a film which is still in production.

\section{REFERENCES}

Bennett, Bruce and Strauss, Jennifer (1998) The Oxford Literary History of Australia. Oxford and Melbourne, Oxford University Press.

Bradford, Clare (2001) Reading Race. Carlton South (Vic. Australia), Melbourne University Press.

Dalziell, Rosamund (1999) Shameful Autobiographies. Carlton South (Vic. Australia), Melbourne University Press.

Dennis, C J (1991) Hist! Ill. P. J. Gouldthorpe. Ringwood, Puffin Books.

Egan, Ted and Ingpen, Robert (1997) The Drover's Boy. Melbourne, Lothian Books.

Halliday, Alison (1999) 'Double Vision: poem, picture and imagination' in S. Clancy and D. Gilbey (eds) Something to Crow About. Wagga Wagga, Centre for Information Studies, pp. 97-106.

Healy, J.J. (1978) Literature and the Aborigine in Australia. St Lucia, University of Queensland Press.

Heylen, Jill and Jellett, Celia (1983) Someone is Flying Balloons. Adelaide, Omnibus Books.

Kendall, Henry (1869) Leaves from the Australian Forest. Melbourne, George Robertson.

Kendall, Henry (1880) Songs from the Mountains. Sydney, Maddock.
Kendall, Henry (1989) The Last of His Tribe. III Percy Trezise and Mary Haginikitas. Sydney, Collins Publishers and Anne Ingram Books.

Mappin, A. R. (1975) Sing in Bright Colours. Perth, Westbooks.

Moore, T. Inglis (ed) $(1957,1975)$ Selected Poems of Henry Kendall. Sydney, London, Angus \& Robinson.

Noonuccal, Oodgeroo (1990) My People ( $3^{\text {rd }}$ ed) Brisbane, Jacaranda Press.

O'Connor, Mark (1988) Two Centuries of Australian Poetry. Melbourne, Oxford University Press.

Paterson, A. B. (1970) Waltzing Matilda. III. Desmond Digby. Sydney, Collins. (1973) Mulga Bill's Bicycle. III. K. and D. Niland. Sydney, Collins. (1981) The Man from Snowy River. Ill. A. Macarthur-Onslow) Sydney, Collins.

Pretty, Ron (1992) Outlook. Melboume, Longman Cheshire.

Read, Peter (2000) Belonging: Australians, Place and Aboriginal Ownership. Cambridge, Cambridge University Press.

Turner, Ethel (1994) Walking to School. IIl. Peter Gouldthorpe. Melbourne, Lothian Books.

Wajnryb, Ruth (2001) The Silence: How Tragedy Shapes Talk. Sydney, Allen \& Unwin.

Wilde, W. et al (1991) The Oxford Companion to Australian Literature. Oxford, Melbourne, Oxford University Press. 


\section{ACKNOWLEDGEMENTS}

Images from The Drover's Boy (1998) by Ted Egan and Robert Ingpen (Port Melbourne, Lothian Books) reproduced with permission.

Image from The Last of His Tribe (1989) by Henry Kendall, illustrated by Percy Trezise and Mary Haginikitas (Sydney, Collins Publishers Australia in association with Anne Ingram Books) reproduced with permission from HarperCollins.

\section{BIOGRAPHICAL NOTE}

Alison Halliday completed her doctorate on the ideology of Australian poetry anthologies for children two years ago. Since then she has continued to research and publish on poetry for children and on life stories. She has a particular interest in the role of memory in shaping texts. She teaches at Macquarie University and at WEA in Sydney. 